\title{
Research on Key Issues in the Development of China's Internet Finance
}

\author{
Youfang Jin \\ Zhejiang University \\ Hangzhou, China
}

\begin{abstract}
Internet finance has gone through the process from the indulgent free development to the regulations, and the governance and institutional arrangements based on the nature of Internet finance shall be understood authentically. In order to solve the problem of the missing legal system to regulate the Internet Finance field, it is urgent to reshape the concept of rule by law and restructure the system. The measures to the regulation development of Internet finance and the institutional arrangements in the future is to pay great attention to the supervision and division of Internet finance and functional supervision's realization, Internet financial risk and platform business integration, the consumer protection and path of Internet finance as well as the relationship between Internet financial information disclosure and buyer's bewaring. It is essential to make a discussion on the key problems in the Internet financial development.
\end{abstract}

Keywords-Online Lending Institutions; Functional Supervision; Regulatory Sandbox; Information Disclosure

\section{INTRODUCTION}

Attributed to the innovation-pursuing and inclusive governance by the relevant departments like National Financial Supervision and Management, the Internet finance has been flourishing in short order since its establishment, and it also results from the shortage of legal system and free growth of conventional financial laws and legislative resources concentrated in the traditional formal financial institutions. The free development of Internet finance does not violate the laws and regulations fundamentally, and it is just nonstandard. Owing to the irregularities existing in online financing, huge losses and influence on the society are brought, stimulating the conflicts. The appropriate system arrangement shall be provided for the normative development of Internet finance, since the good system design and arrangement will not only provide broad space for the development of Internet finance but also create stability and order for the society as the powerful driving force for social development.[1]

\section{REgUlATORY DIVISION AND SUPERVISION FUNCTION'S REALIZATION OF INTERNET FINANCE}

\section{A. Regulatory Division and Supervision Function's Realization of Internet Finance}

1) CSRC is More Suitable for Regulating Online Lending Financing Business

In the Internet credit financing (debt financing) supervision, the network lending regulation is the most controversial. Who is the most appropriate regulator of online lending financing at the central level, CSRC or CBRC? According to the way of securities financing, both debt financing and equity financing fall into the category of financing. Without changing the financing nature of the demand side (individual / enterprise), the online lending usually adopts the equity certificate and oneto-many capital aggregation behavior, and the lending of Internet finance is actually the debt-based public funding. Based on the logic that the financing behavior of Internet finance should be unified management by specialized department, CSRC is the most appropriate body for supervision at the central level. Before CSRC obtains the powers mentioned above, it just needs to set up the generalized securities and empower when revising Security Law. However, there is missing legal basis for CBRC's supervision on network lending financing and it will be difficult to centralize the legislation. CSRC is selected to regulate the online lending financing in the vast majority of countries in the global, such as America’s Prosper and Lending Club supervised by SEC.

2) Query of Regulatory Function's Realization of “Dual Responsibility" System

In terms of the specific regulatory system of online lending, the establishment of Internet financial supervision authority of provincial local government is the biggest change of regulation system from Guidance on Promoting the Healthy Development of the Internet jointly published by ten Ministries including the People's Bank of China on July $18^{\text {th }}, 2015$ to Approach to Online Lending. As stipulated in the fourth articles and related provisions of Approach to Online Lending, CBRC shall be responsible for formulating the supervision and management system for online lending information intermediaries business activities, implementing the behavior supervision, guiding and cooperating with the local governments on the institutional supervision and risk disposition of online lending information intermediaries, and building the trans-departmental and crossregional regulatory coordination mechanism. The provincial 
people's governments shall be responsible for the institutional supervision of online lending information intermediaries under the jurisdiction, filing registration and canceling the records for the intermediaries involved in online lending information, as well as evaluating and classifying the intermediaries which finish the filing registration. And it shall also accept the information disclosure bulletins and relevant reference documents of online lending intermediaries, and take charge of the risk prevention and disposal of online lending information intermediaries. On the whole, CBRC is responsible for the behavior supervision of network lending information intermediary, and the local government take charge of the institutional supervision. Moreover, it is theoretically contradictory and practically difficult in the division of labor between behavior supervision and institutional supervision.

\section{B. Internet Financial Risk and Platform Business Integration}

1) Limited and Controllable Internet Financial Risk

It is a fact that there is risk of Internet finance and it is necessary to face up to what provides the basis for the risk problems. But the Internet financial risk shall not be exaggerated. The losses caused by financial indulgence are different from the Internet financial risk, and risk of regulated Internet finance can be limitedly controlled with the help of Internet technology. The regulatory Internet banking itself is negligibly risky, but fraudulence, swindling and criminal risk become the big risk source. The relevant departments shall strengthen the establishment and implementation of the system in the way of criminal offence like fraudulence and swindling. The decentralized supervision policy and measures for administrative supervision and management, which are regardless of the national conditions and unconformable to the reality, may be the risk source. At present, the Internet finance including the online lending finance is moving forward in the process of exploration, and the vast majority of authentic Internet finance (including debit and credit) without violating the laws and regulations is operating in the framework of law.

\section{2) Business Integration of Internet Lending Platform}

Internet financial platform as a special carrier shall be permitted as long as it never infringes the business of the formal financial institutions, and the functional supervision shall be enhanced. Only the platform with multiple products and multi-functional operation can survive effectively. The platform in the Internet finance is the priority among priorities, in which both sides between debtor and creditor cannot directly connect in general case, but the debtor-creditor relationship is shaped by the capital. The key to the trade occurring between debtor and creditor is that both parties believe the opportunity given by the platform and the trading rules controlled by it. The online lending is most distinguished by that the debtor and creditor involved in the loaning project are not allowed to face to face when the borrowing occurs, it is impossible to verify the physical person and thing and it is unlikely to make a detailed confirmation, investigation and evaluation. For the lender, the platform serves as a "gatekeeper", and the investors are able to make decisions easily, conveniently and accurately because of the integrated services and professional risk control services provided by the platform involved in online lending.
Customer transactions volume as well as commission income depend on the reputation and level of online lending institutions, and the adoption of multi-product and multifunctional service can guarantee the improved reputation and standardize development of the online lending platform on the basis of survival. Neither serving as the credit intermediary nor the pure information intermediary, the lending information provider acts as the role of gatekeeper to protect the investors and consumer.

\section{3) The Establishment of "Regulatory Sandbox" Trial- and-Error Mechanism}

From the perspective of regulatory convenience, the orientation and supervision of information intermediary are indeed straightforward, and it is difficult to obtain the profit for the pure information intermediary involved in the private lending on the aspect of enterprise survival. The existing pure information online lending intermediaries domestically scarcely make profits. In this regard, the Internet lending platforms standing out from the market testing are suggested to adopt the franchising comprehensive business pattern, namely compound intermediary form which is to add the individual license service on the basic function of information intermediary.[2] In terms of the business scope of network lending institutions, it is expected to control in the scope of information intermediary without arbitrariness and to encourage innovation and inclusiveness. And it shall be expanded in a reasonable way and implement the integrated business model. Those businesses that can be carried out shall be proposed in the supervision practice. With respect to some new business, the method of "Regulatory Sandbox" can be learned and examined the safety before its promotion.

\section{Internet Financial Consumer Protection and Pathway}

1) Online Lending Platform's Responsibility of Protection

Based on the protection on the vulnerable groups under the circumstance of information asymmetry, financial consumer is usually defined as that the natural persons, legal persons or other organizations buying financial investment products or accepting services from the financing institutions are categorized into professional financial consumers and general financial consumers. Among them, those meeting the following requirements shall be considered as the professional financial consumers: The professional investment institutions as well as the natural persons, legal persons or other organizations with the certain financial resources, professional ability and risk tolerance. And the scope of professional financial consumers and the certain standards like financial resources, professional ability and risk tolerance shall be stipulated by the financial regulatory institutions. The general financial consumers are non-professional financial consumers. [3]The idea of protecting the legitimate rights and interests of financial consumers is always correct and it runs through the whole legislative process in the effective practice. In the loan financing, the investor and the consumer is the least protected, resulting in the loss of principal and interest of the loans (since it is not equity and trust investment). For the sake of attracting the investment and 
enhancing the reputation of the platform, the Internet lending institutions and platforms are the most active to protect the interests of investors and consumers. On the contrary, they may be likely to damage the interests of investors in the way of irresponsible escaping and fraudulence. Rules and regulations work to develop what is good and discard what is bad and motivate the initiative of the outstanding Internet lending platforms. The legal system shall empower the online lending institutions and platforms to a certain extent, allowing them to protect investors and consumers while fully exercising the rights. On the basis of effective risk control, they can keep improving the credence if their own. The platforms shall provide credit enhancement for the third-party insurance, guarantees, reserve funds and special funds, and all steps beneficial to protect investors' interests shall be encouraged.

2) Reasonable Rights to be Empowered to Online Lending Platform

Facts have proved that the other stipulations like information disclosure and self-bearing loss are extremely necessary but fail to work well, so that it cannot play a big role in the debt-service lending. To put it simply, borrowing is about debt service, in which the borrower shall be liable for debt paying and the financing intermediary can also restrict the borrower's behavior. The platform shall be able to verify the information and credit of the borrower and remove the unqualified borrowers from the lending platform, and the borrower can be required to provide the sufficient credit guarantee. In brief, the safety essence for both investors and consumers are the orientation on the network lending platform and the possibility of moderate rights empowered to the platform, strengthening its ability to protect the investors and consumers.

\section{Internet Financial Information Disclosure and Bargainer's Bewaring}

In the Internet financing, the information asymmetry and serious dependence on information are existing.[4]Fund demand and the information from the users can never meet the decision-making demand of investors. For the investors (lender) involved in network lending, information plays a vital role and the inadequate information or information flaws occurring in the loaning will lead to the investment decision mistake. Once the fault happens in the investment decision-making, it may lose everything and follow-up information makes no sense. Internet finance intensifies the information asymmetry, and only the responsible platform can provide the investors with accurate information needed for investment decisions. There are too many variables in the borrower and it is difficult for the information intermediary to provide investors with decisionmaking information in the context of insufficient external credit foundation. In particular, online lending institutions which are merely positioned as information intermediaries, imposed excessive restrictions on business ability and deprived of the inherent right are unable to undertake the function of indeed protecting investors.

In the design of Internet finance legal system, some value orientations which are theoretically proper but practically defective usually occur, along with unequal rights and obligations as well as difficultly in implementing. For example,
"Investors shall assume the responsibility for losses" (namely Buyer's Bewaring) makes sense at the theoretical level, but the risks and consequences entailed by buyers in "Buyer's Bewaring" can only be market risk. And the buyers shall not be responsible for the losses caused by the moral risks or institutional defect outside the market risk. However, in China's market practice, the investors actually bear losses far beyond the market risk owing to the principle of "Buyer's Bewaring” or system embodiment in a conscious or unconscious way. [5]In the Internet financial network lending system, the system of "Buyer's Bewaring” shall be adopted only when all arrangements for the relevant reasonable system are used up, the platforms are able to perform responsibility and the borrower's moral risks are restricted institutionally. (1) At present, the general investors have the lower ability to understand and judge the risks in the face of financial products on account of the seriously asymmetric information and the increasingly complicated financial products. And under the circumstance of missing credit information needed in online assessment, it shall be cautious when promoting "Buyer's Bewaring”. As written in the twelfth article of Approach to Online Lending, the borrowers shall fulfill the obligations: The financing project shall be authentic and legitimate and the loan fund shall be used in accordance with the agreed purpose and not for lending or other purposes; to ensure the matched ability to repay the borrowings in accordance with the contract. In the debtor-creditor relationship, it is hard to ensure the use of funds and the repayment, and the losses for financial institutions like banks mainly arise from the changed use of funds by borrowers as well as failure in implementing the repayment terms. Among them, the lack of sufficient ability to track and supervise is the key. In the lending of Internet finance, ethical risk may occur in the borrowers when there are missing or lacking online lending institutions or platforms to track and supervise the follow-up use of funds or other behaviors of the debtors, eventually damaging the interests of lenders. Thus, the intermediaries providing the online lending service shall have the legal rights and responsibilities to supervise the borrowers or exercise surveillance on behalf of the creditors.

\section{CONCLUSIONS}

In a bid to regulate the development of Internet finance, it is supposed to apply appropriate institutional design and arrangements. In terms of supervision, CSRC is considered to be more suitable for regulating the network lending financing business. However, there are great disputes in the regulatory function' s realization of “Dual Responsibility” system, namely that CBRC is responsible for behavior supervision of network lending information intermediary and the local government takes charge of the institutional supervision. The Internet financial risk is limited and controllable, and the regulatory authorities shall allow the business integration of Internet lending platforms by taking the attitude of inclusiveness and encouraging innovation. Confronted with the new business, the

\footnotetext{
${ }^{(1)}$ As stipulated in Article 3 of Approach to Online Lending, "Both debtor and the creditor shall bear the risk of borrowing by upholding the principle of voluntary lending, honesty and trustworthiness, selfbearing responsibility and risks.
} 
method of "Regulatory Sandbox" can be learned and adopted to verify. Some measures to protect the financial consumers shall be taken by the platforms embarking on online lending. In view of the serious information asymmetry existing in the Internet financing, it shall be cautious to promote the "Bargainer's Bewaring", and the intermediaries providing the online lending service shall have the legal rights and obligations to supervise the borrowers or exercise surveillance on behalf of the creditors.

\section{REFERENCES}

[1] [1]T. Chen, "Analysis of System Function From the Perspective of Human Study," From Academic Research, 2016, Phase 8.(In Chinese)

[2] D.Yang, "Definition of Financial Consumers Concept," Jurists Review, 2014,Phase 5(In Chinese)

[3] J.N. Li, "Legal Definition of Financial Consumers--Based on the Construction of Special Protection Mechanism for China's Financial Consumer," Zhejiang Social Sciences, 2011,phase 6 (In Chinese)

[4] J. Chen, "Transmutation from Investors to Financial Consumers," Chinese Journal of Law, 2011,Phase 5.(In Chinese)

[5] As stipulated in Article 3 of Approach to Online Lending, "Both debtor and the creditor shall bear the risk of borrowing by upholding the principle of voluntary lending, honesty and trustworthiness, self-bearing responsibility and risks". 